\title{
Low clonal propagation in Atlantic and Mediterranean populations of the red gorgonian Paramuricea clavata (Octocorallia)
}

\author{
Joanna Pilczynska ${ }^{1}$, Joana Boavida ${ }^{2}$, Silvia Cocito ${ }^{3}$, Chiara Lombardi ${ }^{3}$, Andrea Peirano ${ }^{3}$, \\ Henrique Queiroga ${ }^{1}$ \\ ${ }^{1}$ Departamento de Biologia and CESAM - Centro de Estudos do Ambiente e do Mar, Universidade de Aveiro, 3810-193 \\ Aveiro, Portugal. \\ (JP) (Corresponding author) E-mail: joanna.pilczynska@wp.pl. ORCID iD: http://orcid.org/0000-0003-4467-4712 \\ (HQ) E-mail: henrique.queiroga@ua.pt. ORCID iD: http://orcid.org/0000-0002-2338-0013 \\ ${ }^{2}$ CCMAR - Centro de Ciências do Mar, Universidade do Algarve, 8005-139 Faro, Portugal. \\ (JB) E-mail: joanarboavida@gmail.com. ORCID iD: http://orcid.org/0000-0001-5265-2498 \\ ${ }^{3}$ ENEA, Marine Environment Research Centre, P.O. Box 224, 19100 La Spezia, Italy. \\ (SC) E-mail: silvia.cocito@enea.it. ORCID iD: http://orcid.org/0000-0002-5607-7002 \\ (CL) E-mail: chiara.lombardi@enea.it. ORCID iD: http://orcid.org/0000-0002-4165-3660 \\ (AP) E-mail: andrea.peirano@enea.it. ORCID iD: http://orcid.org/0000-0001-8847-1760
}

\begin{abstract}
Summary: Clonal propagation is a common feature of benthic marine organisms. In the present study, we investigated the contribution of clonal reproduction in the red gorgonian Paramuricea clavata. Mediterranean populations of $P$. clavata were severely affected by mass mortality events caused by increased water temperature in 1999 and 2003. The populations are characterized by slow growth and episodic recruitment, but after the observed mortalities, an unexpectedly high recovery rate was observed in the severely affected populations from the Ligurian Sea, NW Mediterranean. Ten years after the last mortality event, we investigated the contribution of clonal propagation in populations from the Ligurian Sea, where some populations were highly affected by mass mortality events, and from the Atlantic, where mortality was never observed. All individuals were genotyped for nine microsatellite loci. The contribution of clonal reproduction varied from $0 \%$ to $13 \%$ and did not differ significantly between affected and unaffected populations. We confirm by using genetic markers that clonal propagation in $P$. clavata is not common, and that the contribution of clones is too low to play an important role in red gorgonian reproduction and cannot contribute to population recovery at sites that have been affected by mass mortality events.
\end{abstract}

Keywords: Paramuricea clavata; gorgonian; clonal reproduction; mortality; microsatellite; climate change.

Baja propagación clonal en poblaciones atlánticas y mediterráneas de gorgonia roja Paramuricea clavata (Octocorallia)

Resumen: La propagación clonal es una característica común de organismos bentónicos marinos. En el presente estudio, hemos investigado la contribución de la reproducción clonal en la gorgonia roja Paramuricea clavata. Las poblaciones mediterráneas de $P$. clavata fueron severamente afectadas por eventos de mortalidades masivas en 1999 y 2003 , causadas por incrementos de la temperatura del agua. Estas poblaciones están caracterizadas por un crecimiento lento y reclutamientos periódicos, sin embargo, tras las mortalidades observadas, una inesperada elevada tasa de recuperación fue observada en las poblaciones severamente afectadas del Mar de Liguria, NO Mediterráneo. Diez años después del último evento de mortalidad, investigamos la contribución de la propagación clonal en poblaciones del Mar de Liguria, donde algunas poblaciones fueron fuertemente afectadas por eventos de mortalidad masiva, así como del Atlántico, donde estas mortalidades masivas nunca han sido registradas. Todos los individuos fueron genotipados para 9 loci microsatélites. La contribución de la reproducción clonal varió de 0 a $13 \%$ y no difirió significativamente entre poblaciones afectadas y no afectadas. Confirmamos, mediante el uso de marcadores genéticos, que la propagación clonal no es habitual en $P$. clavata y que la contribución de clones es demasiado baja como para jugar un papel importante en la reproducción de la gorgonia roja, siendo insuficiente para la recuperación de lugares afectados por eventos de mortalidad masiva.

Palabras clave: Paramuricea clavata; gorgonia; reproducción clonal; mortalidad; microsatélite; cambio climático.

Citation/Como citar este artículo: Pilczynska J., Boavida J., Cocito S., Lombardi C., Peirano A., Queiroga H. 2017. Low clonal propagation in Atlantic and Mediterranean populations of the red gorgonian Paramuricea clavata (Octocorallia). Sci. Mar. 81(1): 103-110. doi: http://dx.doi.org/10.3989/scimar.04473.05A

Editor: M. Pascual.

Received: May 9, 2016. Accepted: January 11, 2017. Published: February 15, 2017.

Copyright: (c) 2017 CSIC. This is an open-access article distributed under the terms of the Creative Commons Attribution (CC-by) Spain 3.0 License. 


\section{INTRODUCTION}

Clonal propagation is widespread among marine invertebrates and a number of studies have attempted to explain its evolutionary importance and adaptive significance (Coffroth and Lasker 1998, McFadden 1991). Sexual reproduction is important for generating diversity, so this mode of reproduction increases the evolutionary potential of populations (Williams 1975). Asexual reproduction, however, not only allows domination of the community by the most adapted genotype (Miller and Ayre 2004) but has also a significant role in the colonization of new areas, since it may allow for a faster increase in abundance compared with sexual reproduction (Dybdahl and Kane 2005, Mergeay et al. 2006).

Asexual reproduction may play an important role in corals, supporting high population growth rates (Lasker 1988). In species with frequent vegetative propagation and low recruitment of larvae produced through sexual reproduction, a few successful clones may dominate the population (McFadden 1991, 1997). Additionally, observations of skewed sex ratio, frequently reported in octocorals (Kahng et al. 2011), may be generated by asexual reproduction, as in the Caribbean gorgonian Plexuara sp. populations (Brazeau and Lasker 1989). This species reveals an extremely low contribution of males, but reproductive output is high, suggesting that eggs develop parthenogenetically. If this is the case, Plexuara sp. clones, spread locally by fragmentation (Lasker 1984) and between reefs by the dispersal of parthenogenetic eggs, may reach wide geographic distributions. Chen et al. (2002) found a high contribution of clonal reproduction in a local population of the gorgonian coral Junceella fragilis from Taiwan. The population was dominated by only two distinct genotypes, probably as a result of multiple clonal reproduction events following colonization by two founder individuals. Numerous cnidarian species may change their reproductive mode and increase or decrease the contribution of clonal reproduction to recruitment in response to environmental changes. As reported in Coffroth and Lasker (1998), the lowest genotypic diversity, meaning the highest contribution of clones, may be related to wave action, as in the gorgonian Plexuara kuna populations from the Caribbean (Lasker et al. 1998). Wave action promotes the detachment of the colony branches, but fragments need calm periods to reattach to the substratum and become established, so the highest contribution of clones is found at sites with intermediate wave impact. Changes in reproductive mode may occur seasonally. The soft coral Alcyonium spp. from the northwestern Pacific exclusively uses sexual reproduction during the summer, so clonal reproduction becomes more important in winter, when animals do not spend energy on sexual propagation (McFadden 1991). Clonal reproduction may also be promoted by human activities, i.e. anchoring and fishing gear, causing detachment od colonies (Harmelin and Marinopoulos 1994). Detached coral fragments may reattach to the substratum and create a new colony (e.g. Smith and Hughes 1999).
The red gorgonian (Paramuricea clavata, Risso 1826) is widely distributed in the western Mediterranean Sea (Carpine and Grasshof 1975) and along the Portuguese coast of the Atlantic (Boavida et al. 2015). Assemblages dominated by $P$. clavata are common on vertical surfaces with low irradiance and intense water flow (Ballesteros 2006), with the highest population abundance between 15 and $35 \mathrm{~m}$ (Linares et al. 2008). The species is known to reproduce almost exclusively by sexual propagation (Coma et al. 1995a, b). In the Mediterranean Sea synchronous spawning occurs twice a year in June (Coma et al. 1995b). Fertilization, embryogenesis and maturation of the planula larvae take place on the surface of the mother colony (Linares et al. 2007). The reproductive effort of $P$. clavata increases with colony size (Coma et al. 1995a, Cupido et al. 2012). Also, male reproductive success increases with colony height (Mokhtar-Jamaï et al. 2013). Coma et al. (1995a) reported that large colonies (height $>40 \mathrm{~cm}$ ) are generally scarce in the population from the Medes Islands (NW Mediterranean), constituting less than 3\% of colonies, but their contribution to the production of gametes was of the order of $40 \%$ of female gametes and $33 \%$ of male gametes. In contrast, the recruitment rates are considered to be low. Linares et al. (2007) reported that, during two years of monitoring the population from the Medes Islands, none of the settled polyps in the study area survived longer than seven months.

Paramuricea clavata may also reproduce asexually by fragmentation of the colony or stolonization. Colonies originating from fragments differ in appearance from the typical fan-shaped colonies. They are attached to the substratum at several points and have several parallel branches growing up from a branch lying on the substrate (Coma et al. 1995b). This morphology may not only be a result of asexual reproduction, but also an adaptation to hydrodynamics, such as a turbulent current regime, or the result of partial colony mortality in the past (Cerrano and Bavestrello 2008). Colonies originating from stolons are connected to the mother colony until they reach around $15 \mathrm{~cm}$ in height, but the connection breaks up with time (Coma et al. 1995b). Based on colony morphology, Coma et al. (1995b) evaluated the frequency of colonies originating from asexual reproduction to be $0.3 \%$ by fragmentation and $2 \%$ by stolonization. However, these estimates on the prevalence of clonal reproduction have never been validated with genetic markers. Only in the study of Mokhtar-Jamaï et al. (2013) was it found that 4 of 104 colonies shared the same genotype, but the authors excluded repeated genotypes since their paper did not focus on clonal propagation.

The impact of climate-induced mortality events on the $P$. clavata reproduction mode has not been studied so far, despite the fact that the species has experienced severe damage in the Mediterranean Sea in the past. Two mass mortality events in the summers of 1999 and 2003 reduced $P$. clavata colony density by $78 \%$ in the Ligurian Sea (NW Mediterranean), affecting mainly the large, most fertile individuals (Cupido et al. 2008). These events affected a wide variety of species and taxa of hard-bottom communities and were observed in the 


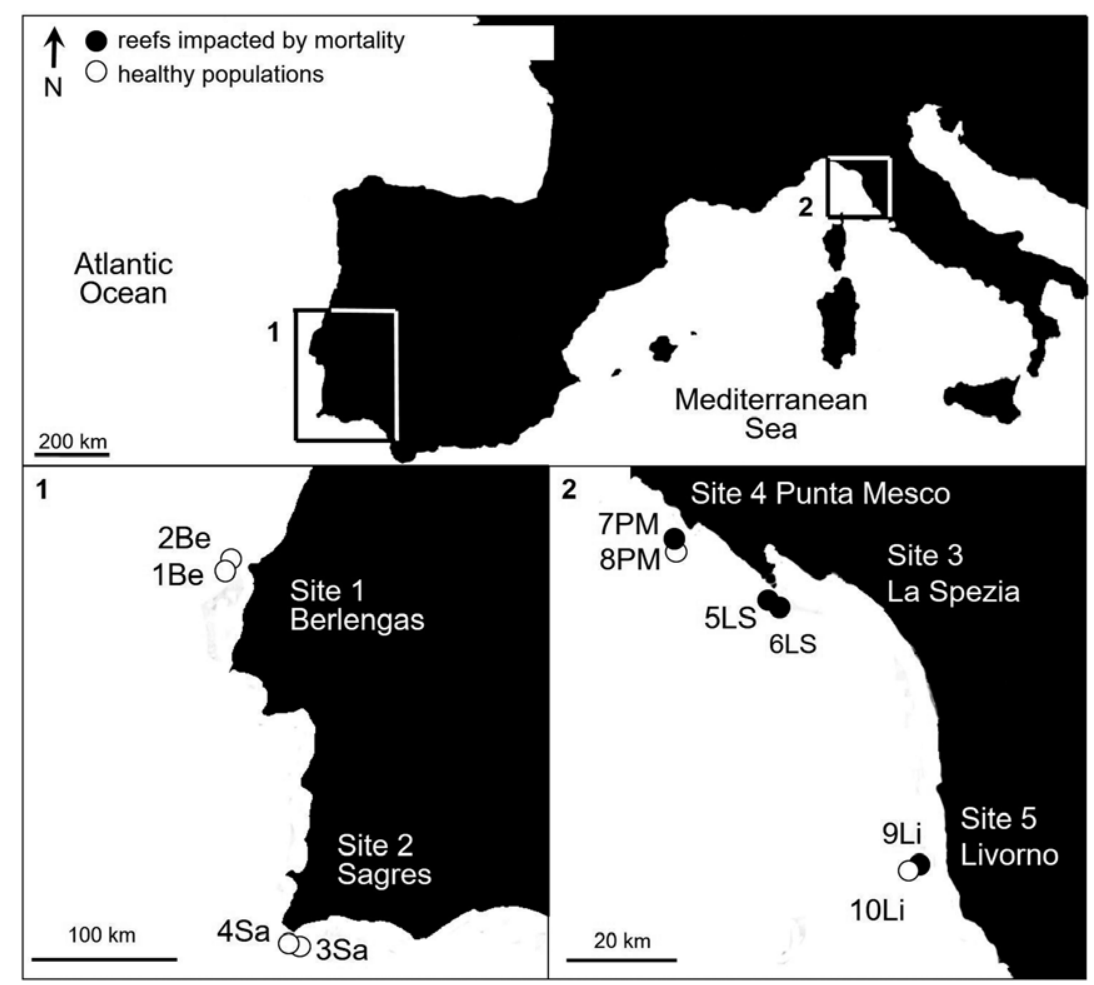

Fig. 1. - Sampling sites in the Atlantic and the Mediterranean, showing P. clavata reefs impacted by mass mortality events (black circles) and healthy populations (white circles).

entire NW Mediterranean region, over several thousand kilometres of coastline (Garrabou et al. 2009, Perez et al. 2000). The mortality was caused by unusually high sea water temperatures with an enhanced stratification, causing thermal stress and food limitation due to lack of water mixing (Coma et al. 2009). In 2003, the temperature down to the thermocline was between $1^{\circ} \mathrm{C}$ and $3^{\circ} \mathrm{C}$ above the mean monthly temperature in the NW Mediterranean (Garrabou et al. 2009). Damage intensity decreased with depth, and populations dwelling below the thermocline (25-30 m) were significantly less affected than shallower ones (Linares et al. 2005, Peirano et al. 2009). Red gorgonian populations from the Atlantic Ocean were never monitored, although we may suspect that lower water temperatures in the Atlantic have prevented temperature-driven mass mortality events. The Portuguese coast is influenced by strong and persistent upwelling events during spring and summer (Relvas et al. 2007), which decrease surface temperature and mix the water column, preventing the formation of a strong thermocline. In the Mediterranean, temperature-related mortality events have impacted the reproductive output from sexual propagation by decreasing not only colony density but also fecundity (Linares et al. 2008). The recovery of impacted assemblages may be delayed because of low growth rate $\left(0.8 \mathrm{~cm} \mathrm{yr}^{-1}\right.$ in colony height, Coma et al. 2001) and late age of first reproduction (7-13 year, Coma et al. 1995a). However, an unexpectedly high recovery rate caused by an unusually high recruitment rate was observed in the La Spezia population (Ligurian Sea, NW Mediterranean) in the years following the 2003 event. The density of recruits increased from 2.6 recruits per $\mathrm{m}^{2}$ in 1998 (before mortality) to around 6 in 2007 and 2008 (Cupido et al. 2009). Mass mortality affected mainly the large, most fertile individuals, and fecundity of survivors decreased (Linares et al. 2008). Therefore, the sexual reproduction output was reduced after the event. However, asexual reproduction, if present, may be expected to stay at the same level, since colony fragmentation does not depend on fecundity. If this is the case, we may expect that clonal propagation to be more frequent at sites affected by mass mortality.

In the present work we used microsatellite markers for the first extended study of asexual reproduction in the red gorgonian. We also investigated whether clonal propagation plays an important role in $P$. clavata reproduction at sites that have been affected by mass mortality in the recent past.

\section{MATERIALS AND METHODS}

\section{Sampling}

In order to compare the contribution of clonal reproduction according to mortality history, we analysed populations from two regions. Samples were taken by scuba divers from three sites in the Mediterranean Sea that were affected by past mass mortality events, and from two sites in the Atlantic Ocean where P. clavata mass mortality had never been reported. The distance between the two sites in the Atlantic was approximately $280 \mathrm{~km}$, whereas the Mediterranean sites were separated by distances of 20 to $60 \mathrm{~km}$ (Fig. 1). At each site, two different reefs, separated by 200-500 m, were chosen (Fig. 1, Table 1). Two of the reefs from the Mediterranean were sampled below the thermocline, 
$106 \cdot$ J. Pilczynska et al.

Table 1. - Sampling site characteristics: depth range of sampled reefs, year of past mass mortality events and number of the $P$. clavata colonies sampled at each reef.

\begin{tabular}{|c|c|c|c|c|}
\hline Site & Reef code & Depth (m) & Past mass mortality events & No. of colonies sampled \\
\hline \multirow{3}{*}{ Berlengas } & $1 \mathrm{Be}$ & $19-24$ & No & 30 \\
\hline & $2 \mathrm{Be}$ & $8-12$ & No & 30 \\
\hline & $3 \mathrm{Sa}$ & $11-12$ & No & 17 \\
\hline Sagres & $4 \mathrm{Sa}$ & $21-22$ & No & 2 \\
\hline \multirow{2}{*}{ La Spezia } & $5 \mathrm{LS}$ & $18-22$ & 1999 and 2003 & 29 \\
\hline & $6 \mathrm{LS}$ & $19-20$ & 1999 and 2003 & 30 \\
\hline \multirow{3}{*}{ Punta Mesco } & 7PM & $21-23$ & 1999 and 2003 & 30 \\
\hline & $8 \mathrm{PM}$ & $28-29$ & No & 30 \\
\hline & $9 \mathrm{Li}$ & $23-25$ & 2006 & 25 \\
\hline Livorno & $10 \mathrm{Li}$ & $30-31$ & No & 30 \\
\hline
\end{tabular}

so these populations were not affected by mass mortality (Table 1). At Punta Mesco P. clavata colonies were deeply affected by mortality down to $25 \mathrm{~m}$ depth: all colonies showed an injured surface. Colonies beyond $25 \mathrm{~m}$ were not affected (Peirano et al. 2009). The population from La Spezia was highly affected during two events of mortality: $90 \%$ of colonies suffered total or partial mortality (Cupido et al 2009). The population from Livorno was affected in a smaller-scale mortality event that occurred in 2006 but only colonies down to $25 \mathrm{~m}$ were affected (Di Fiore M, pers com). The sampled colonies were a mixture of both individuals that survived mass mortality and post-mortality recruits. Three plots separated by at least $5 \mathrm{~m}$ were randomly chosen at every reef. At each plot we randomly sampled up to ten different ramets (discrete, spatially isolated colonies) within a circle with a 0.5 to $1.0 \mathrm{~m}$ radius. Plot size depended on the colonies' density, since we sampled all colonies present in the plot, regardless of their size. Around 3-4 cm of colony branch tip was taken and stored in an individual plastic tube under the water. Samples were placed on ice during transport and preserved in ethanol after arrival to the laboratory, no later than 3 hours after collection. In the following text, each reef will be referred to by its code (see Table 1). Fieldwork was carried out in 2013 and 2014. An exception to this sampling scheme was Site 2 (Sagres, Atlantic Ocean), where just two plots (17 colonies) were sampled at Reef 3 and only two colonies at Reef 4 , because of low gorgonian abundance.

Sampling for $P$. clavata poses several logistic challenges, because of the sparse distribution of populations over very large geographical areas and a depth that limits sampling by conventional SCUBA diving. Additionally, the impacted populations in the Mediterranean are located at shallower depths $(<25$ to $30 \mathrm{~m}$ ) than the non-impacted populations $(>30 \mathrm{~m}$, Huete-Stauffer et al. 2011, Linares et al. 2005). This has prevented the development of a balanced sampling design that could account for the effects of geographical region, mortality history and depth. Accordingly, in the present study only two non-impacted and four impacted reefs were sampled in the Mediterranean, whereas three non-impacted and no impacted reefs were sampled in the Atlantic.

\section{Molecular methods}

Coral DNA was extracted using an E.Z.N.A. Mollusc DNA Kit according to the manufacturer-supplied handbook. We analysed nine microsatellites, developed by Agell et al. (2009) and Mokhtar-Jamaï et al. (2010), following the protocols published by the authors. Loci Par_a, Par_b, Par_d, Par_f and Par_m were amplified in a $10 \mu \mathrm{l}$ solution of dNTPs $(0.25 \mathrm{mM}$ each $)$, selected primers $\left(0.25 \mu \mathrm{M}\right.$ each), $4 \mathrm{mM}$ of $\mathrm{MgCl}_{2}, 1 \mathrm{x}$ manufacturer-supplied buffer and $0.25 \mathrm{u}$ DFS-Taq DNA Polymerase (Bioron). The PCR programme was: 2 min $94^{\circ} \mathrm{C},\left(10 \mathrm{sec} 94^{\circ} \mathrm{C}, 20 \mathrm{sec}\right.$ annealing temperature, 1 $\left.\min 72^{\circ} \mathrm{C}\right) \times 30,5 \min 72^{\circ} \mathrm{C}$. Annealing temperature for particular loci was: Par_a: $59^{\circ} \mathrm{C}$, Par_b: $47^{\circ} \mathrm{C}$, Par_d: $51^{\circ} \mathrm{C}$, Par_f, Par_m: $52^{\circ} \mathrm{C}$. To amplify loci Parcla_9, Parcla_10, Parcla_14 and Parcla_17, a total genomic DNA was dissolved in 10- $\mu$ l solution of dNTPs (125 $\mu \mathrm{M}$ each), selected primers (0.5 $\mu \mathrm{M}$ each), 0.25 u GoTaq ${ }^{\circledR}$ DNA Polymerase (Promega) and $1 \mathrm{x}$ manufacturer-supplied PCR buffer. The PCR programme was 3 $\min 94^{\circ} \mathrm{C},\left(1 \min 94^{\circ} \mathrm{C}, 1 \min 60^{\circ} \mathrm{C}, 1 \min 72^{\circ} \mathrm{C}\right) \times 30$, 5 min $72^{\circ} \mathrm{C}$. The length of amplified fragments was analysed on an ABI 3730XL Genetic Analyzer using an internal size standard (GeneScan 500 LIZ).

\section{Detection of clonal reproduction}

Genetic data from the Mediterranean Sea (Punta Mesco, La Spezia and Livorno) were taken from Pilczynska et al. 2016. The DNA fragment lengths were analysed with STRand (Toonen and Hughes 2001). Scored microsatellite fragment sizes were then visualized in $\mathrm{R}$ environment using the MsatAllele_1.02 package to track and reanalyse scoring errors. MICROCHECKER v.2.2.3 (Van Oosterhout et al. 2004) was used to estimate null allele frequency and to check for scoring errors owing to stutters and large allele dropout. Linkage disequilibrium among all pairs of loci was tested in GENEPOP 4.2. (Raymond and Rousset 1995, Rousset 2008) with significance levels determined by the Markov chain method (dememorization=5000, batches $=500$, iterations $=10$ 000). GIMLET 1.3 .3 (Valiére 2002) was used to identify matching multi-locus genotypes indicating clonal origin of the colonies. The probability of identity (PI) was calculated in GIMLET using the allele frequencies to quantify the ability of the microsatellite markers to discriminate between two individuals. Two PI approaches were used: biased, for randomly mating individuals $\left(\mathrm{PI}_{\text {theoric }}\right)$ and unbiased, correcting for small sample sizes $\left(\mathrm{PI}_{\text {unbiased }}\right)$. In order to determine whether parent/offspring pairs or siblings can have the the same observed genotype, specific probability values $\left(\mathrm{P}_{\text {par-off }}\right.$ and $\left.\mathrm{P}_{\text {sib }}\right)$ were calculated in 
GIMLET for each pair of colonies. Matching genotypes were classified as clones when the PI and P values mentioned above were less than 0.05. Genotypic richness was calculated as $\mathrm{N}_{\mathrm{g}} / \mathrm{N}$ in order to estimate the maximum contribution of sexual reproduction to local recruitment (Coffroth and Lasker 1998). $\mathrm{N}_{\mathrm{g}}$ is the number of unique multi-locus genotypes (or multilocus lineages, corresponding to the best possible identification of distinct clonal lineages; Arnaud-Haond et al. 2007) at each reef and $\mathrm{N}$ is the number of colonies sampled at each reef. This index varies between 1 when all individuals have unique genotype and 0 when one genotype is shared between all ramets. Observed genotypic diversity $\left(\mathrm{G}_{\mathrm{o}}\right)$ (Stoddart and Taylor 1988) was calculated as: $G_{0}=1 / \Sigma g_{i}^{2}$, where $g_{i}$ is the frequency of $i^{\text {th }}$ genotype. Genotypic evenness $\left(\mathrm{G}_{\mathrm{o}} / \mathrm{N}_{\mathrm{g}}\right)$ (Coffroth and Lasker 1998) represents the number of colonies per genet and reaches 1 when individuals are distributed evenly among the clones. Genotypic evenness approaches 0 when one clone dominates the population. Genotypic diversity, calculated as $\mathrm{G}_{\mathrm{o}} / \mathrm{G}_{\mathrm{e}}$, measures the relative contribution of clonal and sexual propagation in a population (Baums et al. 2006). $G_{e}$ is the total number of individuals genotyped per site (ArancetaGarza et al. 2012).

In order to evaluate the association between the occurrence of past mass mortality events and frequency of clonal propagation, we used log-linear analysis of frequency tables (implemented in Statistica 10). This analysis was restricted to Mediterranean populations because there are no records of past mass mortality events in the Atlantic.

\section{RESULTS}

Among 253 colonies sampled, 250 were successfully genotyped to identify colonies with identical multi-locus genotypes, i.e. clones ( 2 colonies were lost during the dive and 1 did not amplify at any loci). All loci amplified and were polymorphic, except Par-b, which was monomorphic in both populations from $\mathrm{La}$ Spezia, according to the 0.95 frequency criterion. No large allele dropout or scoring errors were detected by MICRO-CHECKER at any locus. The mean null allele frequency across all reefs varied from 0 for Parcla_10, Parcla_17 and Par_f to 0.18 for Par_m. No significant linkage disequilibrium was observed between any pair of loci (all p>0.05 after FDR correction), so all loci were considered genetically independent. Mean number of alleles per locus equalled 14. The probability of identity for pooled samples for all loci was $1.93 \times 10^{-12}$ $\left(\mathrm{PI}_{\text {theoric }}\right)$ and $1.28 \times 10^{-12}\left(\mathrm{PI}_{\text {unbiased }}\right)$, both values indicating a low probability of misidentifying clones. An exception was Site 2 (Sagres), where a high percentage of PCR failure was observed, affecting mostly Par_a, Par_d (over 50\% of individuals did not amplify), Parcla_9 and Parcla_10 (no individuals amplified). Therefore, we may have too low power to detect identical multi-locus genotypes. $\mathrm{P}_{\text {par-off }}$ and $\mathrm{P}_{\text {sib }}$ values for all individuals from Reef 3 with the same genotype were higher than 0.05 , indicating that we cannot reject a hypothesis that these genotypes were obtained randomly through sexual reproduction. Therefore, all colonies from Sagres were assumed to be individual genets.

The contribution of clones was low, although colonies generated from clonal reproduction were detected at all sites. Out of the 250 colonies genotyped, we obtained 236 unique multi-locus genotypes and 7 genotypes that appeared more than once (identical multi-locus genotypes [IMG]). In the Atlantic, 2 IMG were found at Reef $1 \mathrm{Be}$ (in total 4 colonies out of 30, which constitutes 13\%), whereas in the Mediterranean Sea, 1 IMG was found at 6LS, 2 at 7PM, 1 at 8PM and 1 at $9 \mathrm{Li}$ (in total 10 colonies, which constitutes 6-13\%). Colonies sharing identical genotype were detected always within one plot (within a circle with 0.5 to $1.0 \mathrm{~m}$ radius). None of the multi-locus genotypes were shared between different plots. Clones were not detected at 2Be, 5LS and 10Li.

The contribution of sexual reproduction to local recruitment (genotypic richness) varied between 0.93 and 1 . Genotypic richness $\left(\mathrm{N}_{\mathrm{g}} / \mathrm{N}\right)$ was the lowest at Reef $1 \mathrm{Br}$ and Reef $7 \mathrm{PM}$ and the highest at reefs $2 \mathrm{Be}$, $3 \mathrm{Sa}, 5 \mathrm{LS}$ and $10 \mathrm{Li}$, where no clonal propagation was observed. Genotypic evenness $\left(\mathrm{G}_{\mathrm{o}} / \mathrm{N}_{\mathrm{g}}\right)$ and genotypic diversity $\left(\mathrm{G}_{\mathrm{o}} / \mathrm{G}_{\mathrm{e}}\right)$ revealed the same pattern (Table 2 ). Unique genets were never shared by more than two colonies.

Log-linear analysis of frequencies indicated no overall differences in contribution of clonal reproduction between reefs impacted by mass mortality and healthy populations in the Mediterranean $\left(\chi^{2}=0.74\right.$, $\mathrm{df}=1, \mathrm{p}=0.39$ ).

\section{DISCUSSION}

This study examined for the first time the contribution of asexual reproduction in the red gorgonian Paramuricea clavata using molecular markers. Our findings corroborates that clonal propagation is not common for

Table 2. - Genotypic diversity in P. clavata based on ten microsatellite loci; Reef 4 (Sagres) was excluded from analysis due to the small number of samples. $\mathrm{N}$, number of colonies in population; $\mathrm{Ng}$, number of genets; $\mathrm{N}_{\mathrm{g}} / \mathrm{N}$, genotypic richness; $\mathrm{G}_{\mathrm{o}}$, observed genotypic diversity; $\mathrm{G}_{\mathrm{o}} / \mathrm{N}_{\mathrm{g}}$, genotypic evenness (number of ramets per genet); $\mathrm{G}_{\mathrm{e}}$, expected genotypic diversity; $\mathrm{G}_{\mathrm{o}} / \mathrm{G}_{\mathrm{e}}$, genotypic diversity.

\begin{tabular}{|c|c|c|c|c|c|c|c|c|c|c|}
\hline \multirow{2}{*}{$\begin{array}{l}\text { Site } \\
\text { Reef }\end{array}$} & \multicolumn{2}{|c|}{ Berlengas } & \multirow{2}{*}{$\begin{array}{l}\text { Sag. } \\
3 \mathrm{Sa}\end{array}$} & \multicolumn{2}{|c|}{ La Spezia } & \multicolumn{2}{|c|}{ Punta Mesco } & \multicolumn{2}{|c|}{ Livorno } & \multirow[t]{2}{*}{ Mean (sd) } \\
\hline & $1 \mathrm{Be}$ & $2 \mathrm{Be}$ & & $5 \mathrm{LS}$ & $6 \mathrm{LS}$ & 7PM & 8PM & $9 \mathrm{Li}$ & $10 \mathrm{Li}$ & \\
\hline $\mathrm{N}$ & 30 & 28 & 16 & 29 & 30 & 30 & 30 & 25 & 30 & $27.6( \pm 4.6)$ \\
\hline $\mathrm{N}_{\mathrm{g}}$ & 28 & 28 & 16 & 29 & 29 & 28 & 29 & 24 & 30 & $26.3( \pm 5.6)$ \\
\hline $\mathrm{N}_{\mathrm{g}} / \mathrm{N}$ & 0.93 & 1 & 1 & 1 & 0.97 & 0.93 & 0.97 & 0.96 & 1 & $0.95( \pm 0.08)$ \\
\hline $\mathrm{G}_{\mathrm{o}}$ & 26.5 & 28.0 & 16.0 & 29.0 & 28.1 & 26.5 & 28.1 & 23.1 & 30.0 & $25.3( \pm 6.6)$ \\
\hline $\mathrm{G}_{\mathrm{o}} / \mathrm{N}_{\mathrm{g}}$ & 0.95 & 1 & 1 & 1 & 0.97 & 0.95 & 0.97 & 0.96 & 1 & $0.95( \pm 0.09)$ \\
\hline $\mathrm{G}_{\mathrm{e}}$ & 30 & 28 & 16 & 29 & 30 & 30 & 30 & 25 & 30 & $27.6( \pm 4.6)$ \\
\hline $\mathrm{G}_{\mathrm{o}} / \mathrm{G}_{\mathrm{e}}$ & 0.88 & 1 & 1 & 1 & 0.94 & 0.88 & 0.94 & 0.93 & 1 & $0.90( \pm 0.15)$ \\
\hline
\end{tabular}


this key species. Additionally, our results indicate that past mortality history of Mediterranean populations does not affect the level of asexual reproduction.

Coma et al. (1995b) reported that colonies originating from clonal reproduction constitute around $2 \%$ of the red gorgonian population, but that study was based on morphological characters, such as colony shape and presence of stolons connecting mother and daughter colonies. The employment of genetic markers allowed for a much more reliable results. In our study, 14 colonies (5.6\% of all examined colonies) had genotypes that appeared more than once (IMG). At two reefs $13.3 \%$ of the colonies (4 out of 30) shared a multilocus genotype. At four reefs, however, all sampled colonies had unique multi-locus genotypes, suggesting that in these populations clonal reproduction does not take place or is infrequent. Previous genetic studies on $P$. clavata did not report occurrence of clonal propagation. In Mokhtar-Jamaï et al. (2011) the distance between sampled colonies was not mentioned, so we cannot exclude the possibility that the distance was too large to detect clones. Mokhtar-Jamaï et al. (2013), however, found four pairs of colonies sharing the same multi-locus genotype. In this case colonies were separated by less than $5 \mathrm{~cm}$ and the probability that they share an identical genotype by chance, through sexual reproduction, was very low. These four colonies constitute $3.8 \%$ of the investigated population, whose population was of the same order of magnitude as the one reported here. The study of Mokhtar-Jamaï et al. (2013) was not focused on clonal propagation, so the authors excluded repeated genotypes from further analysis and did not discuss this phenomenon. The genotypic richness and diversity values in our study were high at all reefs $\left(\mathrm{N}_{\mathrm{g}} / \mathrm{N}>0.93, \mathrm{G}_{\mathrm{o}} / \mathrm{G}_{\mathrm{e}}>0.88\right)$, indicating that all populations rely on sexual reproduction as the dominant mode of propagation. Previous studies have reported that clonal propagation in octocorals is most common among tropical soft coral species in the families from the Alcyoniina suborder, including Alcyoniidae, Nephtheidae, and Xeniidae and in Clavulariidae from the Stolonifera suborder (Simpson 2009). However, other tropical gorgonians are also known to propagate asexually. The gorgonian Plexuara kuna is able to dominate the local community with a small number of clones, reaching high colony densities probably faster than via sexual reproduction (Coffroth and Lasker 1998). The gorgonian coral Junceella juncea from Taiwan relies on clonal propagation to maintain established populations, as was confirmed by the low values of genotypic diversity $\left(\mathrm{G}_{\mathrm{o}} / \mathrm{G}_{\mathrm{e}}\right.$ between 0.217 and 0.650) (Liu et al. 2005).

The number of clones found in our study may also be a result of sampling error. Colonies grow in the dense aggregations and it may be difficult to distinguish separate ramets. Additionally, it is possible to sample the same colony twice. However, during our fieldwork we paid special attention to the base of sampled colonies to be sure they were separated. Additionally, sampling was always conducted by a team of two divers, so one person could constantly monitor which colonies were being sampled. Also, clones were detected in the study by Mokhtar-Jamaï et al. (2013), so we may expect clonal reproduction in $P$. clavata to occur.

Asexual propagation in the $P$. clavata population from La Spezia (reefs 5LS and 6LS) cannot be responsible for the high number of recruits present at this site after the mortality event, as recorded by Cupido et al. (2012). The results of the present study indicate that factors other than clonal propagation-such as increased reproductive output and/or recruitment rate after the mortality event, decreased competition because of a larger area of available substratum or migrations from other populations-enable disturbed populations to recover after being affected by climatic events. Similarly, the red coral Corallium rubrum, impacted by mass mortality events in the Mediterranean Sea, has a limited capability for clonal propagation, so the only way to recover from disturbance is via sexual propagation (Garrabou et al. 2001). In the study of Ledoux et al. (2010) only 8 out of 81 C. rubrum colonies shared 3 multi-locus genotypes, but they were closely related in space and were therefore considered by the authors as belonging to the same individual. This reproductive feature of habitat-forming species has an important meaning for the conservation of coralligenous assemblages, which are one of the most species-rich communities in the Mediterranean Sea (Ballesteros 2006).

Man-induced sources of red gorgonian detachment (anchors, fishing apparatus, involuntary handling by divers, Harmelin and Marinopoulos 1994) may produce colony fragments that increase clonal reproduction frequency in sites subjected to human activities. However, this does not seem to be the case here, since the highest number of clones was found in Punta Mesco, located in the Cinque Terre Marine Protected Area where fishing, anchoring and diving is prohibited.

In the Sagres population, a high percentage of PCR failure was observed, possibly indicating incompatibility of primers. Colonies from Sagres differed from all other populations investigated here, being bright yellow, not purple. Yellow colonies are reported to be rare in the Mediterranean, whereas purple colonies with yellow apical branches are more common (Carpine and Grasshoff 1975). Further studies are necessary to determine whether the yellow colonies from the Sagres population belong to a separate species or are a phenotype of the same species.

\section{CONCLUSIONS}

Clonal propagation does not play an important role in P. clavata. Although asexual reproduction is more frequent than indicated by previous assessments, it was not the dominant factor accounting for population recovery at sites that had been affected by past mass mortality events because i) maximum prevalence of clones was $c a .13 \%$ and ii) there were no differences in clone prevalence between impacted and non-impacted sites. Infrequent clonal propagation, in addition to sporadic recruitment and low larval dispersal, makes recovery a difficult and time-consuming process. There is, therefore, a definite need to develop conservation plans to 
protect local populations and existing colonies by controlling anthropogenic stressors, such as harbouring, trawling and diving.

\section{ACKNOWLEDGEMENTS}

The authors wish to thank R. Albuquerque, F. Fernandes, J. Rodrigues and E. Mancuso for help during the fieldwork. This work is a part of the research project DiverseShores - Testing associations between genetic and community diversity in European rocky shore environments (PTDC/BIA-BIC/114526/2009), funded by the Fundação para a Ciência e Tecnologia (FCT) under the COMPETE program supported by the European Regional Development Fund. This work was co-funded through a MARES Grant. MARES is a Joint Doctorate programme selected under Erasmus Mundus coordinated by Ghent University (FPA 2011-0016). See www.mares-eu.org for extra information.

\section{REFERENCES}

Agell G., Rius M., Pascual M. 2009. Isolation and characterization of eight polymorphic microsatellite loci for the Mediterranean gorgonian Paramuricea clavata. Conserv. Genet. 10: 2025-2027. https://doi.oro/10.1007/s10592-009-9885-1

Aranceta-Garza F., Balart E.F., Reyes-Bonilla H., et al. 2012. Effect of tropical storms on sexual and asexual reproduction in coral Pocillopora verrucosa subpopulations in the Gulf of California. Coral Reefs 31: 1157-1167. https://doi.org/10.1007/s00338-012-0941-9

Arnaud-Haond S., Diaz Almela E., Teixeira S., et al. 2007. Vicariance patterns in the Mediterranean sea: East-West cleavage and low dispersal in the endemic seagrass Posidonia oceanica. J. Biogeogr. 34: 963-976. https://doi.org/10.1111/j.1365-2699.2006.01671.x

Ballesteros E. 2006. Mediterranean coralligenous assemblages: A synthesis of the present knowledge. Oceanogr. Mar. Biol. 44: 123-195. https://doi.org/10.1201/9781420006391.ch4

Baums I.B., Miller M.W., Hellberg M.E. 2006. Geographic variation in clonal structure in a reef building Caribbean coral, Acropora palmata. Ecol. Monogr. 76: 503-519. https://doi.org/10.1890/0012-9615(2006)076[0503:GVICSI]2. $0 . \mathrm{CO} ; 2$

Boavida J., Assis J., Reed J., et al. 2015. Comparison of small remotely operated vehicles and diver-operated video of circalittoral benthos. Hydrobiologia 766: 247-260. https://doi.org/10.1007/s10750-015-2459-y

Brazeau D.A., Lasker H.R. 1989. The reproductive cycle and spawning in a Caribbean gorgonian. Biol. Bull. 176: 1-7. https://doi.org/10.2307/1541882

Carpine C., Grasshof M. 1975. Les gorgonaires de la Méditerranée. Bull. Inst. Océanogr. (Monaco) 71: 1-140.

Cerrano C., Bavestrello G. 2008. Medium-term effects of die-off of rocky benthos in the Ligurian Sea. What can we learn from gorgonians? Chem. Ecol. 24 (S1): 73-82. https://doi.org/10.1080/02757540801979648

Chen C.A., Wei N.V., Dai C.F. 2002. Genotyping the clonal population structure of a gorgonian coral, Junceella fragilis (Anthozoa: Octocorallia: Ellisellidae) from Lanyu, Taiwan, using simple sequence repeats in ribosomal intergenic spacer. Zool. Stud. Taipei 41: 295-302

Coffroth M.A., Lasker H.R. 1998. Population Structure of a Clonal Gorgonian Coral: The Interplay Between Clonal Reproduction and Disturbance. Evolution 52: 379-393. https://doi.org/10.2307/2411075

Coma R., Zabala M., Gili J.M. 1995a. Sexual reproductive effort in the Mediterranean gorgonian Paramuricea clavata. Mar. Ecol. Prog. Ser. 117: 185-192. https://doi.org/10.3354/meps 117185

Coma R., Ribes M., Zabala M., et al. 1995b. Reproduction and cycle of gonadal development in the Mediterranean gorgonian Para- muricea clavata. Mar. Ecol. Prog. Ser. 117: 173-183. https://doi.org/10.3354/meps 117173

Coma R., Linares C., Pola E., et al. 2001. Seguiment temporal de la gorgonia Paramuricea clavata de les illes Medes Exercici 2001. In Zabala M. (ed) Seguiment temporal de l'area marina protegida de les illes Medes. Informe anual any 2001. pp. 5982. Departament de Medi ambient, Generalitat de Catalunya, Barcelona, Spain

Coma R., Ribes M., Serrano E., et al. 2009. Global warming-enhanced stratification and mass mortality events in the Mediterranean. Proc. Natl. Acad. Sci. USA 106: 6176-6181. https://doi.org/10.1073/pnas.0805801106

Cupido R., Cocito S., Sgorbini S., et al. 2008. Response of a gorgonian (Paramuricea clavata) population to mortality events: recovery or loss? Aquat. Conserv. 18: 984-992. https://doi.org/10.1002/aqc.904

Cupido R., Cocito S., Barsanti M., et al. 2009. Unexpected longterm population dynamics in a canopy-forming gorgonian following mass mortality. Mar. Ecol. Prog. Ser. 394: 195-200. https://doi.org/10.3354/meps08260

Cupido R., Cocito S., Manno V., et al. 2012. Sexual structure of a highly reproductive, recovering gorgonian population: quantifying reproductive output. Mar. Ecol. Prog. Ser. 469: 25-36. https://doi.org/10.3354/meps09976

Dybdahl M.F., Kane S.L. 2005. Adaptation vs. phenotypic plasticity in the success of a clonal invader. Ecology 86: 1592-1601. https://doi.org/10.1890/04-0898

Garrabou J., Perez T., Sartoretto S., et al. 2001. Mass mortality event in red coral Corallium rubrum populations in the Provence region (France, NW Mediterranean). Mar. Ecol. Prog. Ser. 217: 263-272. https://doi.org/10.3354/meps217263

Garrabou J., Coma R., Bensoussan N., et al. 2009. Mass mortality in NW Mediterranean rocky benthic communities: effects of the 2003 heat wave. Glob. Chang. Biol. 15: 1090-1103. https://doi.org/10.1111/j.1365-2486.2008.01823.x

Harmelin J.G., Marinopoulos J. 1994. Population structure and partial mortality of the gorgonian Paramuricea clavata (Risso) in the north-western Mediterranean (France, Port-Cros Island). Mar. Life 4: 5-13.

Huete-Stauffer C., Vielmini I., Palma M., et al. 2011. Paramuricea clavata (Anthozoa, Octocorallia) loss in the Marine Protected Area of Tavolara (Sardinia, Italy) due to a mass mortality event. Mar. Ecol. 32: 107-116 https://doi.org/10.1111/j.1439-0485.2011.00429.x

Kahng S.E., Benayahu Y., Lasker H.R. 2011. Sexual reproduction in octocorals. Mar. Ecol. Prog. Ser. 443:265-283. https://doi.org/10.3354/meps09414

Lasker H.R. 1984. Asexual reproduction, fragmentation, and skeletal morphology of a plexaurid gorgonian. Mar. Ecol. Prog. Ser. 19: 261-268. https://doi.org/10.3354/meps019261

Lasker H.R. 1988. The incidence and rate of vegetative propagation among coral reef alcyonarians. Proc. 6th Int. Coral Reef Symp. Townsville 2: 763-768.

Lasker H.R., Kim K., Coffroth M.A. 1998. Production, settlement and survival of plexaurid gorgonian recruits. Mar. Ecol. Prog. Ser. 162: 111-123 https://doi.org/10.3354/meps 162111

Ledoux J.B., Garrabou J., Bianchimani O, et al. 2010. Fine-scale genetic structure and inferences on population biology in the threatened Mediterranean red coral, Corallium rubrum. Mol Ecol. 19: 4204-4216. https://doi.org/10.1111/j.1365-294X.2010.04814.x

Linares C., Coma R., Diaz D., et al. 2005. Immediate and delayed effects of a mass mortality event on gorgonian population dynamics and benthic community structure in the NW Mediterranean Sea. Mar. Ecol. Prog. Ser. 305: 127-137. https://doi.org/10.3354/meps305127

Linares C., Coma R., Mariani S., et al. 2007. Early life history of the Mediterranean gorgonian Paramuricea clavata: implications for population dynamics. Invertebr. Biol. 127: 1-11. https://doi.org/10.1111/j.1744-7410.2007.00109.x

Linares C., Coma R., Zabala M. 2008. Effects of a mass mortality event on gorgonian reproduction. Coral Reefs 27: 27-34. https://doi.org/10.1007/s00338-007-0285-z

Liu S.Y.V., Yu H.T., Fan T.Y., et al. 2005. Genotyping the clonal structure of a gorgonian coral, Junceella juncea (Anthozoa: Octocorallia), using microsatellite loci. Coral Reefs 24: 352-358. https://doi.org/10.1007/s00338-005-0011-7 
McFadden C.S. 1991. A comparative demographic analysis of clonal reproduction in a temperate soft coral. Ecology 72: 1849-1866. https://doi.org/10.2307/1940983

McFadden C.S. 1997. Contributions of sexual and asexual reproduction to population structure in the clonal soft coral, Alcyonium rudyi. Evolution 51: 112-126. https://doi.org/10.2307/2410965

Mergeay J., Verschuren D., De Meester L. 2006. Invasion of an asexual American water flea clone throughout Africa and rapid displacement of a native sibling species. Proc. Roy. Soc. BBiol. Sci. 273: 2839-2844.

Miller K.J., Ayre D.J. 2004. The role of sexual and asexual reproduction in structuring high latitude populations of the reef coral Pocillopora damicornis. Heredity 92: 557-568. https://doi.org/10.1038/sj.hdy.6800459

Mokhtar-Jamaï K., Bottin J., Chaix A., et al. 2010. Characterization of microsatellite loci for the Mediterranean red gorgonian, Paramuricea clavata. Mol. Ecol. 10: 232-236.

Mokhtar-Jamaï K., Pascual M., Ledoux J.B., et al. 2011. From global to local genetic structuring in the red gorgonian Paramuricea clavata: the interplay between oceanographic conditions and limited larval dispersal. Mol. Ecol. 20: 3291-3385. https://doi.org/10.1111/j.1365-294x.2011.05176.x

Mokhtar-Jamaï K., Coma R., Wang J., et al. 2013. Role of evolutionary and ecological factors in the reproductive success and the spatial genetic structure of the temperate gorgonian Paramuricea clavata. Ecol. Evol. 3: 1765-1779. https://doi.org/10.1002/ece3.588

Peirano A., Sgorbini S., Cupido R., et al. 2009. Decadal monitoring of coralligenous and bioconstructional organisms in the Eastern Ligurian Sea. UNEP-MAP-RAC/SPA. In: Pergent-Martini C., Brichets M. (eds), Proceedings of the 1st Mediterranean Symposium on the Conservation of the Coralligenous and Other Calcareous Bio-concretions. Tabarka, 15-16 January 2009. RAC/SPA publ., Tunis: 232-234.

Perez T., Garrabou J., Sartoretto S., et al. 2000. Mass mortality of marine invertebrates: an unprecedented event in the Northwestern Mediterranean. Compt. Rend. Acad. Sci. Paris, Sci. Vie. 323: $853-865$
Pilczynska J., Cocito S., Boavida J., et al. 2016. Genetic Diversity and Local Connectivity in the Mediterranean Red Gorgonian Coral after Mass Mortality Events. PLoS ONE 11: e0150590. https://doi.org/10.1371/journal.pone.0150590

Raymond M., Rousset F. 1995. GENEPOP (version 1.2): population genetics software for exact tests and ecumenicism. J. Hered. 86: 248-249.

Relvas P., Barton E.D., Dubert J., et al. 2007. Physical oceanography of the western Iberia ecosystem: latest views and challenges. Progr. Oceanogr. 74: 149-173. https://doi.org/10.1016/j.pocean.2007.04.021

Rousset F. 2008. Genepop'007: a complete reimplementation of the Genepop software for Windows and Linux. Mol. Ecol. Resour. 8: 103-106. https://doi.org/10.1111/j.1471-8286.2007.01931.x

Simpson A. 2009. Reproduction in octocorals (Subclass Octocorallia): a review of published literature. Available at http://www.ucs.louisiana.edu/ scf4101/Bambooweb/ Research FS.htm

Smith L.D., Hughes T.P. 1999. An experimental assessment of survival, re-attachment and fecundity of coral fragments. J. Exp. Mar. Biol. Ecol. 235: 147-164. https://doi.org/10.1016/S0022-0981(98)00178-6

Stoddart J.A., Taylor J.F. 1988. Genotypic diversity: estimation and prediction in samples. Genetics 118: 705-711.

Toonen R.J., Hughes S. 2001. Increased Throughput for Fragment Analysis on ABI Prism 377 Automated Sequencer Using a Membrane Comb and STRand Software. Biotechniques 31: $1320-1324$.

Valiére N. 2002. Gimlet: a computer program for analyzing genetic individual identification data. Mol. Ecol. Notes 2: 377-379. https://doi.org/10.1046/j.1471-8286.2002.00228.x-i2

Van Oosterhout C.V., Hutchinson W.F., Wills D.P.M., et al., 2004. MICRO-CHECKER: software for identifying and correcting genotyping errors in microsatellite data. Mol. Ecol. Notes 4: 535-538. https://doi.org/10.1111/j.1471-8286.2004.00684.x

Williams G.C. 1975. Sex and Evolution. Princeton University Press, Princeton, New Jersey. 